RU Конструирование учебного курса лингвокраеведческой направленности для иностранных слушателей краткосрочных курсов русского языка

Писарь Н. В., Дронова А. Л., Агульник Е. С.

\begin{abstract}
Аннотация. Цель работы - конструирование учебного курса лингвокраеведческой направленности при обучении иностранных слушателей краткосрочных курсов русского языка в естественной национально-речевой среде на основе коммуникативно-деятельностного подхода. В статье представлен практический опыт конструирования и апробации учебного курса лингвокраеведческой направленности при обучении инофонов русскому языку на краткосрочных курсах. Научная новизна исследования заключается в том, что в нем представлена новая технология конструирования учебного курса лингвокраеведческой направленности при обучении иностранных слушателей русскому языку с учетом коммуникативно-деятельностного подхода; описаны результаты апробации разработанного учебного курса, заключающиеся в быстрой адаптации инофонов к среде изучаемого языка и формировании у обучающихся коммуникативной компетенции. Основными результатами исследования являются определение влияния использования учебного материала с лингвокраеведческой информацией на формирование коммуникативной компетенции, конструирование учебного курса лингвокраеведческой направленности для обучения иностранных слушателей краткосрочных курсов русского языка, обоснование ценности использования данного курса для быстрой социокультурной адаптации инофонов в среде изучаемого языка и формирования у них коммуникативной компетенции.
\end{abstract}

\title{
EN Developing a Course of Linguistic and Local History Orientation for Foreign Students at Short-Term Courses of Russian as a Foreign Language
}

\author{
Pisar N. V., Dronova A. L., Agulnik E. S.
}

\begin{abstract}
The research objective includes developing a course of linguistic and local history orientation for teaching Russian as a foreign language at short-term courses in natural linguistic environment on the basis of the communicative and activity approach. The article describes practical experience of creation and approbation of a course of linguistic and local history orientation for foreign students at short-term courses of Russian as a foreign language. Scientific originality of the study lies in the fact that the authors introduce new methodology to create a course of linguistic and local history orientation for foreign students studying Russian as a foreign language, taking into account the communicative and activity approach; results of an experimental approbation indicate that the course helps foreign students to adapt quickly to the Russian language environment and promotes formation of their communicative competence. The research findings are as follows: the authors show how the use of educational material containing linguistic and local history information promotes formation of students' communicative competence; the paper presents a course of linguistic and local history orientation for foreign students at short-term courses of Russian as a foreign language, justifies efficiency of the course in promoting foreign students' sociocultural adaptation in the Russian language environment and in forming their communicative competence.
\end{abstract}

\section{Введение}

Современная концепция преподавания русского языка как иностранного невозможна без ориентации на социокультурную коммуникацию. В связи с этим в последнее время возникает необходимость в создании 
учебных курсов с учетом места обучения иностранных обучающихся в стране изучаемого языка. По справедливому замечанию И. А. Гурицкой, «учет этого фактора, как свидетельствует опыт, уже с самого начала занятий позволяет не только удовлетворять коммуникативные и познавательные потребности и интересы студентов, но и формировать в их сознании образ нового общества с помощью привлечения доказательных, убедительных фактов и примеров из непосредственно окружающей действительности» [6, с. 118]. Следовательно, лингвокраеведческая информация оказывается значимой составляющей обучения русскому языку как иностранному (далее - РКИ). Под лингвокраеведческой информацией понимаются лексические единицы с регионально-культурным фоном, в качестве которых могут выступать «безэквивалентные и фоновые слова и выражения, даты, ономастическая лексика (топонимы, антропонимы, хрононимы и др.), связанные с конкретным регионом или городом, в котором живут и учатся иностранные студенты» [7, с. 3]. Освоение данных лексических единиц служит формированию лингвокраеведческой компетенции иностранных студентов, которая, в свою очередь, является одним из элементов коммуникативной компетенции.

Необходимость в конструировании учебного курса лингвокраеведческой направленности обусловлена тем, что «учебники и учебные пособия, реализующие федеральный компонент образования в области русского языка как иностранного, недостаточно обеспечивают региональный компонент в преподавании, в результате чего на занятиях по русскому языку как иностранному практически не используется языковой материал, отражающий специфику того или иного региона или города России» [5, с. 425]. Безусловно, в России создаются лингвокраеведческие учебные издания, однако большая их часть написана для крупных городов, таких, как Москва, Санкт-Петербург, Казань, Волгоград и др. $[1 ; 3 ; 5 ; 7 ; 8 ; 10 ; 11]$. В Калининградской области лингвокраеведческие пособия единичны [9], ориентированы на иностранных студентов, обучающихся в вузах в течение нескольких лет. В данных пособиях не всегда представлена актуальная для современной молодежи информация о городе. Соответственно, для Калининградской области необходимость в конструировании учебного курса лингвокраеведческой направленности, учитывающей социокультурные потребности иностранных обучающихся, обозначается особенно остро.

Немаловажной проблемой при конструировании учебного курса лингвокраеведческой направленности оказывается также следование не столько коммуникативному, сколько коммуникативно-деятельностному подходу, который предполагает сопровождение занятий по русскому языку посещением различных мест и экскурсий, непосредственно связанных с изучаемой темой. Особенно значимой данная проблема оказывается при обучении иностранных слушателей на краткосрочных курсах РКИ, где на первое место ставится быстрое погружение в среду изучаемого языка, формирование коммуникативной компетенции в условиях естественного общения на неродном языке.

Следовательно, актуальность настоящего исследования определяется: 1) необходимостью конструирования учебного курса с региональным компонентом для формирования у иностранных обучающихся регионально-культурных фоновых знаний и лингвокраеведческой компетенции как составляющих коммуникативной компетенции; 2) проблемой поиска преподавателем современного учебного пособия лингвокраеведческой направленности для обучения инофонов в Калининградской области; 3) проблемой конструирования учебного курса лингвокраеведческой направленности с учетом коммуникативно-деятельностного подхода для быстрой социокультурной адаптации иностранных обучающихся в стране изучаемого языка.

Для реализации поставленной цели необходимо решить ряд задач:

- определить влияние использования учебного материала с региональным компонентом на регуляцию отношений естественной и искусственной речевой среды;

- установить степень значимости конструирования учебного курса лингвокраеведческой направленности для формирования адекватного речевого поведения и страноведческих знаний иностранных обучающихся;

- осуществить конструирование учебного курса, включающего комплекс заданий с лингвокраеведческой составляющей, который предназначен для формирования коммуникативной компетенции у иностранных обучающихся и их быстрой адаптации в стране изучаемого языка.

Методами настоящего исследования являются: 1) анализ педагогической литературы по лингвокраеведению; 2) изучение и обобщение педагогического опыта использования регионального компонента в обучении РКИ; 3) опытное обучение - один из методов исследования, который «предусматривает проведение массового обучения по предложенной исследователями программе; служит средством внедрения в практику обучения научно обоснованных рекомендаций» с целью «массовой апробации новых приемов и методов обучения, лучших форм организации учебного процесса, усовершенствования учебно-наглядных пособий и др.» [2, с. 206]; 4) наблюдение - эмпирический метод, состоящий «в преднамеренном, систематическом и целенаправленном восприятии явлений с целью изучения их специфических изменений в определенных условиях и поиска смысла этих явлений, который непосредственно не дан» [Там же, с. 180]; 5) метод понимания и интерпретации.

Теоретическая база исследования строится на анализе научных трудов о месте лингвострановедения, в частности лингвокраеведения в теории и методике преподавания РКИ $[2 ; 4 ; 6]$, исследований по практическому внедрению в процесс обучения РКИ регионального компонента [7], работ, посвященных разработке учебных материалов по лингвокраеведению для разных регионов России $[1 ; 3 ; 5 ; 8 ; 10 ; 11]$ и Калининградской области [9].

Практическая значимость исследования состоит в установлении влияния учебного материала с лингвокраеведческой составляющей на категоризацию обучающимися языковых и речевых единиц как принадлежащих 
естественной или искусственной речевой среде, конструировании учебного курса лингвокраеведческой направленности для иностранных слушателей краткосрочных курсов РКИ (уровень А1) и разработке комплекса заданий для указанного учебного курса.

\section{Основная часть}

На сегодняшний день не вызывает сомнения тот факт, что иностранный обучающийся изучает язык прежде всего с целью участия в коммуникации, а коммуникация невозможна без проникновения в новую национальную культуру. Следовательно, для преподавателя важным оказывается тот факт, что в процессе обучения РКИ «задачи обучения русскому языку как совокупности форм выражения неразрывно сливаются с задачами соизучения страны» [4, с. 8]. В связи с этим неудивительно, что в теории и методике преподавания РКИ еще с 70-х гг. ХХ века отечественные и зарубежные ученые говорят о важности преподавания РКИ в лингвострановедческом аспекте.

Как известно, «проблематику лингвострановедения составляют два круга вопросов: 1) лингвистические (анализ языка с целью выявления национально-культурной семантики); 2) методические (приемы введения, закрепления и активизации специфических для изучаемого языка единиц и страноведческого прочтения текстов...» [2, с. 153]. Соответственно, значимыми в лингвострановедении оказываются прежде всего вопросы о принципах отбора языковых единиц, содержащих в себе национально-культурную специфику, которые были бы адекватны современным условиям жизни в стране изучаемого языка, и поиски эффективных методических приемов для использования указанных единиц в процессе коммуникации. Несомненно, обучение иностранному языку вне связи с жизнью затрудняет процесс овладения языком, становится причиной конфликтов, снижает мотивацию обучающихся к освоению языка, поэтому многие исследователи считают, что при обучении инофонов необходимо использовать учебный материал не столько с лингвострановедческой, сколько с лингвокраеведческой информацией [6; 7]. По справедливому замечанию Т. Н. Доминовой, «лингвокраеведческая информация представляет одно из необходимых средств установления отношений с новой социокультурной средой, преодоления культурного шока» [7, с. 3-4]. В результате чего обучающиеся начинают осмыслять язык как живую систему, проявляют интерес к его изучению, быстрее вступают в коммуникацию на иностранном языке, лучше ориентируются в новой среде. Также посредством лингвокраеведческой информации осуществляется управляемое воздействие языковой среды на обучающихся. «Приобретенные на занятиях по русскому языку знания и умения закрепляются и активизируются в реальных ситуациях, возникающих при соприкосновении студентов с окружающей их языковой средой и, следовательно, способствуют формированию коммуникативной компетенции студентов в условиях данного города, региона» [10, с. 325-326]. Следовательно, учебный материал, содержащий лингвокраеведческую информацию, способствует регуляции отношений между естественной и искусственной речевой средой.

Анализ существующих учебных и учебно-методических пособий лингвокраеведческой направленности показал, что авторы при создании указанных материалов отдают предпочтение составлению словников и словарных статей по лингвокраеведению и учебных текстов, включающих данный компонент [4; 7; 8; 10]. Тематически данные пособия наполняются материалом об истории и географическом положении города, музеях, заповедниках, основных достопримечательностях региона, биографии известных деятелей. Однако задания, направленные на освоение указанного учебного материала, зачастую способствуют лишь овладению языковой компетенцией. Недостаточно представлены упражнения на устную коммуникацию, предпочтение отдается заданиям на пересказ, написание сочинений, эссе и т.п. [3; 4; 7; 8; 10; 11]. Кроме того, как справедливо указывает М. В. Абрамова, «в некоторых учебниках по РКИ представлены тексты и задания, в которых рассказывается о посещении иностранцами музеев, театров, балетных постановок, в то время как большинство иностранных студентов, молодых людей в возрасте 18-25 лет, предпочитают проводить свободное время в клубах, кинотеатрах, парках, развлекательных и спортивных центрах, а уровень их лингвистической подготовки не позволяет полноценно воспринимать язык классических пьес» [1, с. 422]. В результате игнорирования авторами данных учебных изданий возрастных, психологических и лингвокультурных особенностей конкретного контингента обучающихся снижается эффективность обучения русскому языку.

Проведенный анализ научных исследований и методических разработок показал, что в основу конструирования современного учебного курса лингвокраеведческой направленности должны быть положены следующие критерии: 1) ориентация на возраст и потребности обучающихся; 2) направленность на формирование коммуникативной компетенции в стране изучаемого языка; 3) наполнение актуальными фоновыми знаниями о регионе обучения и регионально маркированной лексикой; 4) преобладание коммуникативных и интерактивных заданий; 5) тематическое и содержательное пересечение с внеаудиторными занятиями и экскурсионной программой $[1 ; 3 ; 5-8 ; 10 ; 11]$. Только в этом случае учебный курс лингвокраеведческой направленности позволит инофонам овладеть коммуникативной компетенцией в полной мере, расширить кругозор, быстро адаптироваться в новой социокультурной среде.

С учетом указанных выше критериев нами были определены следующие этапы работы над созданием учебного курса лингвокраеведческой направленности:

1) лингвокраеведческая информация отбирается в соответствии с актуальностью и интересами молодежи, классифицируется по принципу значимости и соотнесенности с изучаемой темой, предлагается обучающимся в максимально наглядном виде (фото-, видеоматериалы); 
2) учебный материал с лингвокраеведческой информацией создается по принципу коммуникативной направленности с опорой на уровень владения обучающимися русским языком, имитирует естественную речь, включает в себя интерактивные и игровые элементы, носит творческий характер;

3) учебный процесс сопровождается внеаудиторной и экскурсионной программой, тесно связанной с ним тематически и содержательно;

4) контроль усвоения лингвокраеведческой информации представляет собой творческое задание, направленное на определение степени формирования коммуникативной компетенции на основе использования указанной информации.

В результате был создан экспресс-курс для иностранных слушателей Зимней языковой школы «Калининградская языковая лаборатория». Данный курс рассчитан на иностранных обучающихся из Германии, владеющих русским языком на уровне А1. Целью курса является знакомство инофонов с современными реалиями Калининградской области с учетом внеаудиторных мероприятий и экскурсий, максимально быстрая социокультурная адаптация в регионе и создание ситуаций естественной коммуникации с носителями русского языка.

Курс состоит из 5 тем, на изучение каждой предполагается тратить 4 часа:

1. «Это Кёниг, детка!» - тема посвящена знакомству с Калининградом, интересным фактам из его истории и основным достопримечательностям города и области.

2. «Балтийский федеральный университет имени Иммануила Канта» - тема связана с историей и структурой университета, символом и эмблемой БФУ им. И. Канта, а также с устройством корпуса, в котором проходят занятия по РКИ.

3. «Вкус Калининграда» - в теме говорится об основных заведениях общественного питания города, в которые любят ходить студенты, и предпочтениях калининградцев в еде.

4. «Развлечения в Калининграде» - в теме рассказывается об основных местах для проведения свободного времени молодежью.

5. «Калининградцы. Какие они?» - тема посвящена характеру и специфике поведения калининградцев, а также некоторым особенностям речи жителей города.

Этап I - отбор лингвокраеведческой информации. Лингвокраеведческая информация к каждой теме отбиралась по следующим критериям: 1) актуальность; 2) значимость для понимания культуры России и культурных особенностей Калининградской области; 3) наличие ценностной составляющей; 4) тесная связь с темой курса; 5) приемлемость с точки зрения возрастных и национальных особенностей обучающихся.

Этап II - создание комплекса заданий с лингвокраеведческой составляющей. Комплекс заданий с отобранной лингвокраеведческой информацией создавался на грамматическом материале, соответствующем уровню владения русским языком А1. Задания имели коммуникативную направленность, содержали интерактивные и игровые элементы, фото- и видеоматериалы. Задания оформлялись следующим образом:

1. Предтекстовые задания, которые использовались для снятия лексико-грамматических трудностей при последующем чтении текста. Данные задания были направлены на введение необходимой регионально маркированной лексики, слов и устойчивых сочетаний, необходимых для понимания темы, на семантизацию и систематизацию указанной лексики, а также введение ее в речь. Следует отметить, что каждая языковая единица сопровождалась показом соответствующего фотоматериала.

Также в качестве примеров лексико-грамматических заданий в теме были представлены упражнения на поиск лишнего слова в ряду, однокоренных слов, составление словосочетаний различных типов, а также предложений из списка слов. Указанные лексические и грамматические конструкции функционировали в тексте, предлагаемом инофонам далее.

2. Текст, который был создан по типу монологического высказывания одного из студентов БФУ им. И. Канта на обозначенную тему с вопросом на общее понимание. Кроме того, в каждом тексте освещались актуальные для студентов и жителей Калининграда проблемы, которые могли стать предметом дискуссии. Например, стоит ли восстанавливать Королевский замок? Чего больше в Калининграде - немецкого или русского? Активный или пассивный отдых на море лучше? Нужны ли студентам специально выделенные места в корпусе университета, где они смогут делать совместные проекты, отдыхать и общаться? Нужны ли в Калининграде рыбные рестораны и кафе для вегетарианцев? Какие развлечения интересны современной молодежи - интеллектуальные, спортивные или иные?

В теме 5 также иностранным слушателям предлагался небольшой словарик лексем, функционирующих в речи жителей Калининграда, куда входят такие единицы, как Большая Россия, Балтон, Европа, Кениг, «бензовоз», «быки», «грибы», «девятка», «остров», «площады», «сковородка», «стакан». Данные лексемы имеют отличные от словарных значения и обозначают важные для калининградцев реалии региона, которые часто становятся предметом разговора.

3. Послетекстовые задания коммуникативной направленности. Они состояли из вопросов с выбором ответа «да/нет», вопросов на уточнение информации из текста, на выражение собственной точки зрения по проблемам, затронутым в тексте, и т.п.

Например:

Ваша версия.

1) Как вы ду́маете, почему́ калинингра́дская молодёжь лю́бит гуля́ть в торго́вом це́нтре «Евро́па»? 
2) Как вы ду́маете, почему́ Балтийское мо́ре холо́дное?

3) Как вы ду́маете, в Калинингра́де бо́льше ру́сского и́ли неме́цкого?

Ваше мнение.

1) Где́ вы уже́ бы́ли в Калинингра́де? Что вы ви́дели?

2) Каки́е места́ в Калинингра́де вы хоти́те посети́ть?

3) Как вы ду́маете, Калинингра́д похо́ж на ваш го́род?

4) Как вы ду́маете, что нам де́лать с До́мом Сове́тов?

5) Как вы ду́маете, како́е назва́ние го́рода лу́чше, Калинингра́д и́ли Кёнигсберг?

Кроме этого, в послетекстовых заданиях активно использовались инфографика, оригинальные меню местных ресторанов, актуальное расписание антикафе, интернет-мемы о Калининграде и другие современные иллюстративные материалы.

4. Задания на выход в коммуникацию. После обсуждения текста слушателям предлагалось просмотреть короткие видеоролики, которые для них записали иностранные студенты из Анголы, Индии и Южной Кореи, обучающиеся или прошедшие обучение в калининградских вузах. В данных видеоматериалах студенты высказывали свое мнение по рассматриваемой теме. Слушатели экспресс-курса воспринимали освоенную лингвокраеведческую информацию аудиовизуально, узнавали дополнительную информацию и интересные нюансы жизни студентов в городе, сопоставляли свою точку зрения на ту или иную проблему с позицией других.

Затем инофонам предлагались задания на использование лингвокраеведческой информации в определенной ситуации общения: «На улице», «В ресторане», «В торговом центре», «На море», «В университете», «В столовой», «На стадионе», «В антикафе», «В музее», «На остановке», «На автовокзале», «В русской семье» и др.

5. Игровое задание, позволяющее создать естественную ситуацию речевого взаимодействия.

Этап III - сопровождение учебного процесса. Следующим этапом конструирования учебного курса лингвокраеведческой направленности стала подготовка внеаудиторных мероприятий, тесно связанных с комплексом заданий тематически и содержательно. В результате изучение каждой из тем коррелировало с внеучебной программой слушателей, в освоении которой обучающимся помогали русские студенты. Так, после изучения темы «Это Кёниг, детка!» студенты шли на экскурсию по городу «Кант и Кёнигсберг», а на следующий день обучающимся предлагалось либо побывать на экскурсии «Калининград VS Кёнигсберг: Калининград как многокультурный город», либо поехать на море. После знакомства с темой «БФУ им. И. Канта» инофонам предлагалось посетить «Музей советского детства», расположенный в учебном корпусе, о котором рассказывалось в теме. После прохождения темы «Вкус Калининграда» студенты узнавали о местной кухне и по желанию ходили в интересующие их рестораны и кафе города, были на экскурсии на Хлебозаводе № 1 (г. Калининград), участвовали в мастер-классе «Русский пряник». Изучение темы «Развлечения в Калининграде» продолжилось экскурсией в Музей мирового океана. Последняя тема «Калининградцы. Какие они?» являлась базой для подготовки слушателями собственных видеороликов по итогам освоения экспресс-курса на тему «Что для меня Калининград? Какие для меня калининградцы?».

Этап IV - контроль усвоения лингвокраеведческой информации. В конце экспресс-курса среди иностранных слушателей проводилась викторина на знание Калининградской области, а в качестве творческого задания инофонам предлагалось подготовить видеоролики о том, каким они увидели Калининград и калининградцев.

Указанный учебный курс прошел апробацию в группе слушателей Зимней языковой школы «Калининградская языковая лаборатория» из Грайфсвальдского университета, владеющих русским языком на уровне А1. В результате освоения предложенного экспресс-курса и создания условий для коммуникации с носителями русского языка с использованием регионального компонента иностранные обучающиеся максимально быстро адаптировались в регионе, понимали, где находятся основные достопримечательности города, магазины, кафе, рестораны, узнавали, где можно провести свободное время по интересам. В конце экспресс-курса во время викторины на знание Калининградской области группа А1 показала прекрасное владение лингвокраеведческой информацией и способность к объяснению социокультурной специфики региона; подготовленные иностранными слушателями данной группы видеоролики показали, что обучающиеся прекрасно используют лингвокраеведческую информацию для выражения собственной точки зрения на жизнь региона.

Кроме того, инофоны активно интересовались реалиями Калининградской области, жизнью региона, некоторые из них выразили желание приехать в Калининград еще раз. Многих данный курс мотивировал на дальнейшее изучение русского языка в университете г. Грайфсвальда.

\section{Заключение}

Современное обучение русскому языку как иностранному прежде всего направлено на формирование у иностранных обучающихся коммуникативной компетенции, т.е. способности к общению в условиях среды изучаемого языка. При этом данная среда, с одной стороны, мотивирует инофонов к изучению языка, а с другой - «показывает» им, какие языковые и речевые знания и умения оказываются наиболее востребованными, а какие представляют собой элементы искусственной речевой среды. В этом плане наибольший интерес представляет рассмотрение того, насколько указанная среда «принимает» лингвострановедческую, в частности лингвокраеведческую информацию как средство коммуникации и насколько значимо использовать данную информацию при обучении инофонов русскому языку. 
Настоящее исследование показало, что лингвокраеведческая информация оказывается необходимой составляющей речевого взаимодействия в социокультурной среде изучаемого языка, а использование учебного материала с региональным компонентом демонстрирует иностранным обучающимся, какова естественная речевая среда региона, мотивирует инофонов к изучению языка, позволяет им лучше ориентироваться в новой среде, быстрее овладевать коммуникативной компетенцией.

В результате анализа научной, учебной и учебно-методической литературы было определено, что на сегодняшний день конструирование учебного курса лингвокраеведческой направленности с ориентацией на потребности иностранных обучающихся, устную коммуникацию, современные технологии имеет первостепенное значение, поскольку только с учетом данных составляющих у инофонов будет происходить формирование лингвокраеведческой компетенции и адекватное современным ситуациям общения речевое поведение.

На основе указанных принципов был сконструирован учебный экспресс-курс лингвокраеведческой направленности, который включал в себя 5 тем. Каждая тема состояла из комплекса заданий с лингвокраеведческой составляющей. Лингвокраеведческая информация для заданий отбиралась по принципу актуальности, значимости и приемлемости для обучающихся. Задания создавались в соответствии с уровнем владения обучающимися русским языком, их возрастными и национальными особенностями, имели коммуникативную направленность, содержали интерактивные и игровые элементы, фото- и видеоматериалы. Созданный учебный материал тематически и содержательно коррелировал с внеаудиторной программой. Контроль сформированности лингвокраеведческой компетенции проводился в форме викторины и творческого задания.

Как показала апробация экспресс-курса, инофоны очень быстро прошли социокультурную адаптацию в регионе, овладели лингвокраеведческой компетенцией, проявили интерес к дальнейшему изучению русского языка.

Сконструированный курс лингвокраеведческой направленности, предназначенный для обучения иностранных слушателей краткосрочных курсов русскому языку в условиях естественной национально-речевой среды, оказался значимым для социокультурной адаптации инофонов, формирования у них навыков речевого взаимодействия в новой среде, расширения кругозора и повышения мотивации к изучению русского языка. Полученные результаты могут в дальнейшем стать полезными при разработке учебных курсов лингвокраеведческой направленности для иностранных студентов и слушателей Калининградской области, владеющих русским языком на разных уровнях, могут быть использованы в качестве базы для создания современных учебных изданий в других регионах России.

\section{Список источников}

1. Абрамова М. В. Региональный компонент в конструировании учебного пособия лингвокраеведческого характера // Филологические науки. Вопросы теории и практики. 2018. № 11 (89). Ч. 2. С. 421-424.

2. Азимов Э. Г., Шукин А. Н. Современный словарь методических терминов и понятий. Теория и практика обучения языкам. М.: Русский язык. Курсы, 2019. 496 с.

3. Башарова Н. Ф., Фархетдинова Г. Д. Региональный компонент в преподавании русского языка как иностранного // Казанский педагогический журнал. 2018. № 1. С. 99-102.

4. Верещагин Е. М., Костомаров В. Г. Язык и культура. Лингвострановедение в преподавании русского языка как иностранного. М.: Русский язык, 1990. 246 с.

5. Выхованец Н. А. Региональный компонент как основа культуроориентированной методики преподавания РКИ // Ученые заметки Тихоокеанского государственного университета. 2015. Т. 6. № 4. С. 424-428.

6. Гурицкая И. А. Отбор страноведческого и лингвострановедческого материала в целях включения его в учебные тексты (с учетом места обучения) // Лингвострановедение и текст: сб. ст. М.: Русский язык, 1987. С. $118-125$.

7. Доминова Т. Н. Формирование лингвокраеведческой компетенции на материале историко-культурного пространства Санкт-Петербурга у иностранных студентов в процессе предвузовской подготовки: автореф. дисс. ... к. пед. н. СПб., 2013. 23 с.

8. Панова Е. П., Тюменцева Е. В. Региональный компонент в обучении русскому языку как иностранному // Известия Волгоградского технического университета. Серия «Проблемы социально-гуманитарного знания». 2013. Т. 12. № 2 (105). С. 85-88.

9. Писаревская И. С. Русский язык. Я живу и учусь в Калининграде: учеб. пособие по рус. яз. для студентовиностранцев. Калининград: КГТУ, 2018. 90 с.

10. Пушко О. К. Региональный аспект лингвострановедения в преподавании РКИ // Россия в мировом сообществе: смысловое пространство диалога культур: мат-лы Международного форума «Восточный вектор миграционных процессов: диалог с русской культурой» (г. Хабаровск, 16-17 ноября 2016 г.). Хабаровск: Изд-во Хабаровского гос. ун-та, 2016. С. 325-329.

11. Чупановская М. Н., Маклакова Т. Б. Региональный компонент на занятиях по русскому языку как иностранному (лингвокультурный комментарий краеведческого материала Иркутской области) // Филологические науки. Вопросы теории и практики. 2019. Т. 12. Вып. 3. С. 348-352. 


\section{Информация об авторах | Author information}

RU Писарь Надежда Владимировна ${ }^{1}$, к. филол. н. Дронова Анастасия Леонидовна ${ }^{2}$, к. филол. н. Агульник Екатерина Сергеевна ${ }^{3}$

1,2,3 Балтийский федеральный университет имени Иммануила Канта, г. Калининград

EN Pisar Nadezhda Vladimirovna ${ }^{1}, \mathrm{PhD}$

Dronova Anastasiya Leonidovna ${ }^{2}$, PhD

Agulnik Ekaterina Sergeevna ${ }^{3}$

1,2,3 Immanuel Kant Baltic Federal University, Kaliningrad

${ }^{1}$ NPisar@kantiana.ru, ${ }^{2}$ LSnitlkene@kantiana.ru, ${ }^{3}$ EAgulnik1@kantiana.ru

\section{Информация о статье | About this article}

Дата поступления рукописи (received): 02.06.2020; опубликовано (published): 31.08.2020.

Ключевые слова (keywords): конструирование учебного курса; краткосрочные курсы русского языка; лингвокраеведческая направленность; коммуникативно-деятельностный подход; коммуникативная компетенция; developing an educational course; short-term courses of Russian as a foreign language; linguistic and local history orientation; communicative and activity approach; communicative competence. 